\title{
Comparing the Profitability of Organic and Conventional Broiler Production
}

\section{-Author(s)}

Cobanoglu F

Kucukyilmaz K"

Cinar M"II

Bozkurt M"II

Catli AU"I

Bintas $E^{I I I}$

Adnan Menderes University, Agriculture Faculty, Department of Agricultural Economics, Aydın, Turkey

" Eskisehir Osmangazi University, Agriculture Faculty, Department of Animal Science, Turkey

II Erbeyli Poultry Research Institute, Incirliova/ Aydın, Turkey

\section{Mail Adress}

Corresponding author e-mail address Ferit Cobanoglu

E-mail address: ferit.cobanoglu@adu.edu.tr, fcobanoglu@windowslive.com

\section{घKeywords}

Broiler, conventional, organic, net income, total costs.

\section{ABSTRACT}

Recently, organic broiler chicken production has received more attention worldwide. This study has carried out an economic analysis to compare the profitability of organic versus conventional growing systems per unit of broiler meat production. To achieve this goal, 400 slow-growing broiler chickens (Hubbard Red-JA) were reared in an organic production system, and the same number of fast-growing birds (Ross-308) in a conventional system. The profitability was deduced with an economic analysis that compared total costs and net income. Results showed that organic broiler meat can cost from $70 \%$ to $86 \%$ more with respect to variable and fixed costs when compared with conventional production. The main reasons for the higher cost of organic broiler meat were feed, labor, certification, and outdoor area maintenance. The proportion of fixed costs in total costs was $1.54 \%$ in the conventional system and $7.48 \%$ in the organic system. The net income per $\mathrm{kg}$ of chicken meat in the organic system was $€ 0.75$, which is $180 \%$ higher than chicken meat grown in a conventional system ( $€$ 0.27); however, the price of organic broiler meat sold in the present study was twice as high as that obtained for conventional broilers. In conclusion, organic broiler meat production was more profitable than conventional rearing.

\section{INTRODUCTION}

The organic broiler production system operates according to specific and precise standards of production, and this farming technique is becoming increasingly popular. Organic chicken meat can be summarized as the product of a rearing system that entirely avoids the use of conventionally-grown feedstuffs, including genetically modified organisms, animal by-products, and synthetic additives, feding birds only with organically-grown cereals, oil, seeds and roughage. The system also provides chickens with free access to outdoor areas and applies a lower rearing intensity.

Purchasing statistics indicate that consumers are increasingly interested in naturally-produced or environmentally-friendly products that they perceive as having high nutritional level of nutrition, no contaminants and good flavor. They also prefer products from systems that provide good welfare and health for the birds (Sundrum, 2001; Owens et al., 2006). Indeed, there is a common belief that organic chicken meat is safer and more nutritious than that of conventional broilers, and therefore, an increasing number of consumers are willing to pay a premium for certified organic chicken meat (Magdeliane \& Bloch, 2004; Crandall et al., 2009).

The organic meat sector is currently one of the fastest growing segments of the organic food industry, and poultry accounts for nearly 
two-thirds of this sector. The United States (U.S.) retail sales of organic poultry were $\$ 161$ million in 2005, well under 1 percent of conventional poultry sales (Oberholtzer et al., 2006). However, retail sales of organic poultry have nearly quadrupled since 2003, and estimates of annual growth rates range from 23 percent to 38 percent through the end of the decade, with annual sales reaching nearly $\$ 600$ million by 2010 (NBJ, 2006). Approximately half (51\%) of organic poultry was sold in natural food stores in 2003, $45 \%$ in mass market grocery stores (including conventional grocery, mass merchandiser and club stores) and $4 \%$ of the American organic poultry was purchased through direct sales and other distribution channels (NBJ, 2004).

At the European Union (EU) level, there were 19 million poultry heads in 2007, out of which approximately one-third were laying hens. The organic sector features far more laying hens than the rest of the poultry sector in the entire EU. France is the leading member state. In Turkey, according to data published in 2009, while 34.5 tons of organic poultry meat was obtained from 69,150 broilers, 42,650 laying hens were grown in the same year (MARA, 2010).

It is estimated there would be no marketing problem for organic broiler production in Turkey. In respect to the research study carried out on broiler meat in Ankara, the proportions of the households willing to pay a price increase of 20\%,30\%,50\% and $100 \%$ for organic meat were $5 \%, 4 \%, 3 \%$ and $4 \%$ (16\% in total), respectively. These buyers had the same consumption level. The study results indicated there would be a large demand for organic broiler meat in the city center of Ankara (Koç et al., 2001).

Although there are a relatively limited number of studies that have compared organic and conventional broiler meat quality (Castellini et al., 2002; Ristic, 2004; Jahan et al., 2004; Grashorn \& Serini, 2006; Castellini et al., 2006; Husak et al., 2008; Martino et al., 2008), we have not found a sufficient number of studies that define the differences of cost between organic and conventional broiler production. The cost of broiler production can vary depending on many factors, such as final crop characteristics (the name of the brand and the quality of the product), feed price (basically, cereal prices), climate factors, and genetic lines employed (FAO/EBRD, 1999). Production costs of organic broiler production are higher than the costs of conventional systems. The main difference in cost arises from the feed prices between the two rearing systems, and the main reason for the high cost of organic feed is that organic cereals and soybean are sold at prices that are
50-100\% higher than conventional feedstuffs (USDA AMS, 2003). Other differences in the two systems are small flock size, high mortality rate, and a long rearing period in the organic rearing system (Fanatico, 2008).

This study aims at comparing the profitability of organic and conventional broiler production systems based on an economic analysis that calculates the results of the experimental trial in order to provide attributions for the sector and for future research.

\section{MATERIAL AND METHODS}

This study was conducted in experimental units of the Poultry Research Institute, from October to December of 2006. In total, 400 commercial, slowgrowing (Hubbard Red-JA) and 400 commercial, fastgrowing (Ross-308) one-day-old male and female broiler chicks were used as the animal material in this study. While the slow-growing broilers were reared under organic conditions, the fast-growing broilers were reared under conventional conditions.

In the organic rearing system, the slow-growing broilers were placed in an open-sided, naturallyventilated broiler house. The indoor space (10 birds per $\mathrm{m}^{2}$ ) was equipped with two circular hanging feeders, a bell drinker, a tree-tier perch $(30 \mathrm{~cm} / \mathrm{bird})$ and an outdoor area of $4 \mathrm{~m}^{2}$ per broiler. Two drinkers and two perches were available in the outdoor area, as well. The natural grassland, including an alfalfa and trifolium mixture, was available for consumption in the outdoor area throughout the experimental period, which broilers consumed from 22 days old onward. The house had holes that were opened all day, giving free access to the outdoor area 24 hours per day during the entire experiment. No artificial lighting was applied in the organic system.

In the conventional rearing system, the fast-growing broilers were placed in an open-sided, naturallyventilated broiler house, and standard management practices were applied. The lighting ratio in the fastgrowing broiler house was 23 hours of light to 1 hour of dark each day. Each pen was equipped with two hanging feeders, one bell drinker and two infrared lamps. Bird density was 18 chicks per square meter.

The conventional broiler diet were in mash form, and water was provided ad libitum. Experimental feeds used in both organic and conventional systems were based on corn, wheat, soybean meal, and sunflower meal. In this study similar ingredients were used in the diets of both groups in order to avoid discrepancies that could arise from ingredient composition. In order 
to comply with EC Regulation 1804/99 (EU, 1999), at least 80 percent of the dry matter content of this study's organic feed mixture came from organically-grown ingredients. Soybean meal (GMO-free sources) was the only conventional feed ingredient supplemented to the organic feed mixture at an inclusion level of 20 percent. Alfalfa meal, consisting of dried, whole plants grown under organic farming conditions, was added to the organic feed as a roughage source. Broiler starter and grower diets were given to the fastgrowing broilers between 0 to 21 and 22 to 42 days, respectively. Unlike the conventional schedule, the slow-growing birds were fed a starter diet between 0 to 28 days and a grower diet between 29 to 81 days. Slow-growing birds were slaughtered at 81 days of age, while fast-growing birds were sacrified at 42 days of age. All technical data of the organic and conventional production systems appear in Table 1.

Table 1 - Technical data of organic and conventional production systems

\begin{tabular}{lcc}
\hline & Organic & Conventional \\
\hline Birds at the start of a round (number) & 400 & 400 \\
Birds slaughtered in the round (number) & 396 & 388 \\
$\begin{array}{l}\text { Slaughter age [(duration of a round) } \\
\text { (days)] }\end{array}$ & 81 & 42 \\
Rounds per year (number) & 3.5 & 5.5 \\
Space inside (birds m $^{2}$ ) & 10 & 18 \\
Space outdoor ( ${ }^{2}$ per bird) & $4^{*}$ & 0 \\
Slaughter weight (g) & 2,778 & 2,250 \\
Carcass weight (g) & 2,145 & 1,735 \\
Total broiler meat production (kg year ${ }^{1}$ ) & 2,973 & 3,702 \\
Feed intake in the round (g per bird) & 8,041 & 4,255 \\
Feed conversion rate (kg feed per kg & 2.930 & 1.931 \\
growth) & & \\
Mortality (\%) & 1.00 & 2.83 \\
\hline *The outdoor run must be accessible at least one-third of their life. &
\end{tabular}

Before starting this comprehensive and innovative project, we planned the experimental design very carefully by conducting a pilot study, including where and how we could obtain the inputs. In preparation, we observed current prices for organic broiler meat in the retail market across the country in Turkey. As in the case of other countries, we could not easily find organic input, such as feed intended for organic broiler production, except for one and/or two supplier(s) in Turkey. During the period that this research study took place, there was no production of organic broilers in Turkey. Moreover, there are only three in Turkey as of now, in April 2012. Thus, the prices employed in the study show consistency and reflect the truth. The same statement is valid for chicken meat price. The prices of all variables, including inputs, were very carefully recorded, and all calculations were performed with the
(Euro) $€ 1$ equalling (Turkish Lira) TL 1.85, according to the exchange rate from October to December 2006, which matches the period of the trial. According to current market prices for all the inputs and chicken meat at present, we can still observe that the same prices are valid for all parameters. Our price selection also ensured that there would be no structural price volatility and/or trends for organic feed and organic chicken meat. Similar price stability on chicken meat in Turkey was stressed by Cinar et al. (2006) and Terin et al. (2009).

All variables and fixed cost units were carefully included as regular inventory systems from the beginning to the end of the experiment. The economic analysis was based on one rearing period. Variable costs of feed, chicks, vaccines, other veterinary procedures and medicines, labor, litter, heating, electricity, water, disinfection, and slaughter expenses were taken into consideration. The organic rearing system needs more intensive labor than conventional systems for three critical reasons. First, the slow-growing birds were slaughtered at 81 days of age in the organic system, while fast growing birds were sacrified at 42 days of age under the conventional rearing system. The second point was that while one employer can manage a poultry house with 25,000 broilers in a conventional system, only 4,800 birds can be reared in organic production because of organic poultry regulations. Third, the use of high-level mechanization in conventional rearing would reduce the conventional system's labor requirement. Due to the fact that organic rearing requires more intensive labour than a conventional system, labour cost was calculated as $€ 172.98$ and $€ 10.81$ in organic and conventional rearing for one production period, respectively. We determined this cost unit by using the current price on the basis of the concurrent time period with one worker in daily operations. Then, these labour costs were defined at $€ 0.43$ and $€ 0.03$ per broiler in organic and conventional broiler rearing systems, respectively.

Feed costs were calculated according to the formula: $F C \times(B S+0.5 \mathrm{BD})$, where $F C$ is feed intake per bird, BS is the number of birds that reached the slaughterhouse alive, and BD is the number of birds that died during the rearing period. Feed intake of $\mathrm{BD}$ was multiplied by a half to estimate the amount of feed not consumed by the birds that died at different moments of the rearing period (Bokkers \& De Boer, 2009). Cost per $\mathrm{kg}$ feed were evaluated as $€ 0.43$ and $€ 0.31$ for the organic and conventional systems, respectively, based on recorded data. Then, these feed 
costs were evaluated per broiler for both production systems.

Water intake was evaluated as a ratio of 1.8:1 to feed intake. Therefore, water intake per bird was calculated by multiplying the feed one broiler consumed by 1.8 (Vermeij, 2004). Water, watering costs, and other variable costs were calculated per broiler through a regular inventory system that we recorded (Table 2).

Table 2 - The total variable costs per broiler $(€)$ in organic and conventional broiler rearing systems

\begin{tabular}{lcc}
\hline & Organic & Conventional \\
\hline Chicks & 0.41 & 0.32 \\
Feed & 3.48 & 1.31 \\
Vaccines and medication & 0.13 & 0.07 \\
Labour & 0.43 & 0.03 \\
Litter & 0.08 & 0.04 \\
Heating & 0.16 & 0.14 \\
Electricity & 0.03 & 0.10 \\
Water and watering & 0.54 & 0.01 \\
Cleaning and disinfection of poultry house & 0.19 & 0.27 \\
Slaughter & 0.52 & 0.43 \\
\hline
\end{tabular}

Gross and net margins can be employed for comparison between organic and conventional poultry production (Padel et al., 1997). Net farm income is one of the instruments employed in this aim. This analysis was used in some studies (Van Den Tempel \& Giesen, 1992; Van Calker et al., 2005; Seabrook, 2007; Bokkers $\&$ De Boer, 2009). Net farm income is defined as the difference between revenue and cost, excluding costs of family labor (Van Den Tempel \& Giesen, 1992).

The total variable cost per broiler was obtained by adding the total variable cost units. The variable cost per $\mathrm{kg}$ of broiler meat was obtained by dividing the total variable costs by the carcass weight measured at the end of the trial. Gross production value (sales) was calculated by multiplying the total broiler meat successfully obtained from the experiment by selling price per $\mathrm{kg}$ of bird meat as an average of $€ 1.89$ in the conventional systems and $€ 3.78$ in the organic production systems. In a similar study carried out from March through May of 2006 in lowa, USA, the authors stressed that the average price of organic whole broilers $(\$ 7.03 / \mathrm{kg})$ was $247 \%$ greater than the price for conventional whole broilers $(\$ 2.84 / \mathrm{kg}$; Husak et al., 2008). Gross margin (gross profit) was also calculated by subtracting the variable costs from gross production value [gross margin = gross production value - variable costs] (Inan, 1998; Sheppard, 2004; Van Calker et al., 2005) (Table 3).
Table 3 - Production costs and net income (€) per kg broiler meat produced in organic and conventional systems

\begin{tabular}{lcc}
\hline Production costs and net income $\left(€ \mathrm{~kg}^{-1}\right)$ & Organic & Conventional \\
\hline Selling price (gross production value) & 3.78 & 1.89 \\
Variable costs & 2.80 & 1.59 \\
Fixed costs & 0.23 & 0.03 \\
Total costs & 3.03 & 1.62 \\
Gross margin (profit) & 0.98 & 0.30 \\
Net income & 0.75 & 0.27 \\
\hline
\end{tabular}

The fixed costs consisted of depreciation, maintenance and repair costs for the building and machinery. Costs of the outdoor run were based on the interest rate of the land value, maintenance and fencing, and certification expenses were added to the total fixed costs in the organic system. While closed space inside $\left(40 \mathrm{~m}^{2}\right)$ and outdoor run space $\left(1,600 \mathrm{~m}^{2}\right)$ were considered in organic rearing, only closed space inside $\left(22.22 \mathrm{~m}^{2}\right)$ was calculated for conventional breeding. For conventional and organic systems, investment costs were estimated at $€ 56.76$ per $\mathrm{m}^{2}$ for the building, while investment costs were calculated as $€ 10.81$ and $€ 18.92$ per $\mathrm{m}^{2}$ for the machinery in organic and conventional production systems, respectively. The depreciation of the conventional building was 3.5 percent and 3 percent for the organic building. Maintenance costs for the building amounted to 1 percent for total costs of both systems. Costs of depreciation (6.5 percent) and maintenance ( 2 percent) of the machinery and inventory were similar for both systems (KWIN, 2003/2004). Costs for the outdoor run were based on land interest ( $€ 0.09$ per $\left.\mathrm{m}^{2}\right)$, costs of fencing ( $€ 0.025$ per $\left.\mathrm{m}^{2}\right)$ and maintenance ( $€ 0.02$ per $\mathrm{m}^{2}$ ). For the certification, prices were based on an annual fee of $€ 260$ and an additional $€ 0.05$ per bird (Vermeij, 2004).

Total fixed cost per bird was calculated by dividing total fixed costs by the broilers slaughtered in the final phase of the trial. The fixed costs per kg of broiler meat were calculated on the basis of carcass weight for both rearing systems. Total production costs per $\mathrm{kg}$ of broiler meat were determined by adding the variable and fixed costs. Net income per $\mathrm{kg}$ of broiler meat was calculated by subtracting the selling price of $1 \mathrm{~kg}$ of broiler meat from the total costs (Inan, 1998; FAO/ EBRD, 1999; Rossiter, 2001) (Table 3).

Finally, according to the technical and economic data obtained from this experiment, the total net income gained from one broiler house was used to calculate the house income in one year. This study used 3.5 flocks per year for organic and 5.5 for conventional systems because these production periods are frequently recommended in Turkey (Tumer, 2013) (Table 4). 
Table 4 - Production costs and net income $(€)$ in organic and conventional broiler production systems in a year

\begin{tabular}{|c|c|c|}
\hline Production costs and net income $(€)$ & Organic & Conventional \\
\hline $\begin{array}{l}\text { Total selling price } \\
\text { (total gross production value) }\end{array}$ & $11,249.19$ & $7,003.78$ \\
\hline $\begin{array}{l}\text { Feed } \\
\text { Chicks } \\
\text { Vaccines and medication } \\
\text { Labour } \\
\text { Litter } \\
\text { Heating } \\
\text { Electricity } \\
\text { Water and watering } \\
\text { Cleaning and disinfection of poultry } \\
\text { house } \\
\text { Slaughter } \\
\text { Total variable costs } \\
\text { Depreciation costs of the building } \\
\text { Maintenance costs of the building } \\
\text { Depreciation costs of the machinery and } \\
\text { inventory } \\
\text { Maintenance costs of the machinery } \\
\text { and inventory }\end{array}$ & $\begin{array}{c}4,843.72 \\
567.57 \\
181.62 \\
605.41 \\
113.51 \\
227.03 \\
37.84 \\
756.76 \\
264.86 \\
726.71 \\
8,325.03 \\
68.11 \\
22.70 \\
28.11 \\
8.65\end{array}$ & $\begin{array}{c}2,840.94 \\
713.51 \\
154.59 \\
59.46 \\
95.14 \\
297.30 \\
225.95 \\
11.89 \\
594.59 \\
911.28 \\
5,904.64 \\
44.14 \\
12.61 \\
27.32 \\
8.41\end{array}$ \\
\hline $\begin{array}{l}\text { Costs for the outdoor run } \\
\text { Certification expenses } \\
\text { Total fixed costs }\end{array}$ & $\begin{array}{l}216.22 \\
329.24 \\
673.03\end{array}$ & $\begin{array}{c}0.00 \\
0.00 \\
92.48\end{array}$ \\
\hline Total costs & $8,998.06$ & $5,997.12$ \\
\hline Total gross margin (profit) & $2,924.16$ & $1,099.14$ \\
\hline Total net income & $2,251.13$ & $1,006.66$ \\
\hline
\end{tabular}

\section{RESULTS AND DISCUSSION}

The total variable costs per broiler are indicated in Table 2. Feed expenses comprised a major part of the total variable costs in both rearing systems. The feed costs of organic production ( $€ 3.48$ ) were almost three times higher than the feed costs in the conventional system $(€ 1.31)$.

The economic data (per kg of broiler meat) obtained from the experiment are shown in Table 3. Total costs per $\mathrm{kg}$ of organic broiler meat were calculated at $€ 3.03$, including variable costs $(€ 2.80)$ and fixed costs $(€ 0.23)$. In the conventional system, total costs per $\mathrm{kg}$ broiler meat were estimated at $€ 1.62$, including variable costs (€1.59) and fixed costs (€ 0.03). The results showed that the cost per $\mathrm{kg}$ of broiler meat was higher, at 75 percent for variable costs and 86 percent for fixed costs, in the organic rearing system compared with the conventional production. Higher costs of feed, labor, certification and outdoor access accounted for the higher prices of the organic rearing system.

In addition, the extended slaughter age in the organic production system (81 days vs. 42 days) and the extra feed required for these older chickens is another reason for the higher costs. It has been suggested that slow-growing broiler hybrids are suitable to be slaughtered at the minimum slaughter age of $81 \mathrm{~d}$. The inferior feed conversion efficiency in organically-reared, slow-growing birds compared with fast-growing, conventional lines is another major reason for the higher costs in the organic broiler production system. Furthermore, higher ingredient prices, at $40 \%$ more than conventional raw materials, exaggerated the cost of producing organic chicken meat. These indications proved that feed cost was the main contributor to the total variable costs in both systems. Therefore, a few straightforward calculations make it clear that the proportion of feed cost to total cost would be higher in organic production than a conventional system. Such determinations have been stressed in many studies (Padel et al., 1997; Rossiter, 2001; USDANAMS, 2003; Vermeij, 2004; Fanatico, 2008; Rodenburg et al., 2008).

Bokkers \& De Boer (2009) also calculated that the cost of organic feed was 54 percent higher than the cost of conventional feed. In a similar study, it was found that the cost prices of broilers that received 95 and $100 \%$ organic feed were 4.6 and $7.6 \%$ higher prices compared with from broilers that received $80 \%$ organic feed. The cost price of broilers that received $80 \%$ organic feed was $€ 1.83$ per $\mathrm{kg}$ live weight. The cost prices per $\mathrm{kg}$ live weight for broilers that received 95 and $100 \%$ organic feed were $€ 1.84(+0.8 \%)$ and $€ 1.93$ (+5.4\%), respectively (Rodenburg et al., 2008). In the present trial, feed costs represented $64 \%$ of the total cost of the organic system and $57 \%$ of the total cost of the conventional system. Fortunately, grass consumption in the outdoor area in the organic production system was equivalent to $12 \%$ of the birds' total feed intake (Çınar et al., 2009). This grass consumption would thus reduce their concentrated feed intake (Küçükyılmaz et al., 2007).

Labor requirements for broiler production vary significantly depending upon availability, degree of automation, and the level of unsalaried (farm family) labor involved on a day-to-day basis (Padel et al., 1997). Since the number of birds managed by one worker in organic rearing is lower than the number managed in conventional rearing, the labor cost per broiler is higher in organic production. Water and watering costs were higher because of the watering maintenance of the natural grassland, including the alfalfa and trifolium mixture available for the birds' consumption in the outdoor area throughout the experiment, which they consumed from 22 to 81 days of age. Therefore, water and watering costs comprised $10 \%$ of total costs, accounting for a relatively higher proportion in the organic system. 
While the rate of fixed costs was $1.54 \%$ of the total cost in the conventional system, it was $7.48 \%$ in organic rearing. In a study carried out on organic broiler production in a portable broiler house with a tractor, that rate was $5.84 \%$ (Rossiter, 2001). The main reason for the high fixed costs in the organic system was the cost of outdoor runs, a relatively ample space of $4 \mathrm{~m}^{2}$ per bird, in addition of certification expenses compared with conventional production, which does not use the two parameters indicated above. Since certification costs represented $3.65 \%$ of the total costs of an organic system, if the size of broiler flocks increased, the rate of those costs may be proportionately reduce. In fact, an earlier study emphasized that that rate could drop to $1.48 \%$ of the total costs (Bokkers \& De Boer, 2009).

At the gross margin level, the primary determinants of profitability of all systems analyzed were total feed costs (reflecting price, feed conversion efficiency and slaughter age) and sales value. In the study, gross margins per $\mathrm{kg}$ of bird meat were calculated as $€ 0.98$ and $€ 0.30$ for the organic and conventional systems, respectively. Nevertheless, net income was higher in the organic system $(€ 0.76)$ than in the conventional system (€ 0.27) (Table 3).

For a one-year period, the total variable and fixed costs were higher in the organic system than in conventional production. Although costs in the organic rearing system were $50 \%$ higher, the organic system produced $123 \%$ higher gross margin (profit) than conventional rearing (Table 4). According to the results calculated over the course of one year, gross margin and net income were higher in the organic system, at $230 \%$ and $180 \%$ for organic and conventional systems, respectively. In a similar study, the results showed that organic broiler production would be $156 \%$ more profitable than conventional rearing (Bokkers \& De Boer, 2009).

The better economic performance of organic broiler production simply arises from the ratio between feed prices and sales price per $\mathrm{kg}$ of broiler meat. Net income obtained per $\mathrm{kg}$ of broiler meat represented $14 \%$ of the sales price in the conventional system. If the same net income could also be obtained in an organic system, per $\mathrm{kg}$ broiler meat should be sold at $87 \%$ ( $€ 3.54$ per $\mathrm{kg}$ ) more than the conventional broiler meat's selling price.

\section{CONCLUSIONS}

This study determined that organic broiler meat production was more profitable than conventional systems. The high sales price - which, unfortunately, is the main constraint of the increased demand for organic products - should be studied to determine how to reduce production costs so that a producer need not torely on high price to turn a profit. This type of solution, which focuses on lower production costs and lower selling prices, should extend the demand and market opportunities for organic meat. Given that feed comprised the vast majority of costs, alternative, cheap and sustainable feed resources are probably the most effective way to reduce production costs.

\section{ACKNOWLEDGEMENT}

This project was supported by Turkish Ministry of Agriculture and Rural Affairs, Project No: TAGEM/ HAYSÜD/06/12/01/01.

\section{REFERENCES}

Bokkers EAM, De Boer IJM. Economic, ecological, and social performance of conventional and organic broiler production in the Netherlands. British Poultry Science 2009;50(5):546-557.

Castellini C, Mugnai C, Dal Bosco A. Effect of organic production system on broiler carcass and meat quality. Meat Science 2002;60:219-225.

Castellini C, Dal Bosco A, Mugnai C, Pedrazzoli M. Comparison of two genotypes organically reared: oxidative stability and other qualitative traits of the meat. Italian Jornal of Animal Science 2006;5:29-42.

Crandall PG, Seideman S, Ricke SC, O’Bryan CA, Fanatico AF, Rainey R. Organic poultry: consumer perceptions, opportunities and regulatory issues. Journal of Applied Poultry Research 2009;18:795-802.

Cinar H, Demir A, Kalanlar S, Taskaya B, van Berkum S. Turkish poultry meat sector analysis. 2006. p.1-21. Available from http://www.lei.wur. nl/NR/rdonlyres/24883C99-4400-49BC-9630-BC9688BE2459/97111/ TurkishPoultryMeatSectorAnalysis.pdf.

Çınar $M$, Küçükyılmaz K, Bozkurt $M$, Çatlı AU, Erkek R, Bintaş E. The effect of dietary essential oil mixture supplementation on the growth performance of broilers reared in organic and conventional systems. $1^{\circ}$ Symposium of Organic Agriculture ; 2009 Nov 17-20; Şanlıurfa. Turkey. p. 63-4.

EU. Official Journal of the European Communities. Council Regulation (EC) No 1804/1999. The Council of the European Union. 1999. p.11-12. Available from: http://eur-lex.europa.eu/LexUriServ/LexUriServ.do?uri= OJ:L:1999:222:0001:0028:en:pdf.

Food and Agriculture Organization, European Bank for Reconstruction and development. Poultry meat \& eggs [agribusiness handbooks]. Rome; 1999. p. 6.

Fanatico AC. Organic poultry production in the United States. Fayetteville: National Center for Appropriate Technology; 2008. Available from: http://www.attra.ncat.org/attra-pub/PDF/organicpoultry.pdf.

Grashorn MA, Serini C. Quality of chicken meat from conventional and organic production. 12th European Poultry Conferance; 2006; Verona. Italy. p. 268-9.

Husak R, Sebranek JG, Bregendahl KA. A survey of commercially avaliable broilers marketed as organic, free range and conventional broilers for cooked meat yields, meat composition and relative value. Poultry Science 2008;87:2367-2376. 


\section{Conventional Broiler Production}

Inan $\mathrm{IH}$. Agricultural economics and management. Tekirdag: Agriculture Faculty of Trakya University; 1998.

Jahan K, Paterson A, Spickett CM. Fatty acid composition, antioxidant and lipid oxidation in chicken breast from different production regimes. International Journal of Food Science Technolgy 2004;39:443-453.

Koç A, Akyll N, Ertürk YE, Kandemir MU. The research on demand of organic crop. 2nd Ecologic Agricultural Symposium; 2001; Antalya. Turkey. p. 295-9.

Küçükyılmaz K, Bozkurt M, Çınar M, Çatlı AU, Erkek R, Bintaş E. The effect of an essential oil mixture on the growth performance of broilers reared on organic and conventional systems. 5th National Zootechny Science Congress; 2007; Van. Turkey. p. 78-9.

KWIN. Kwantitatieve informatie veehounderij. Wageningen: Animal Sciences Group; 2003/2004.

Magdeliane P, Bloch M. Development in biological poultry meat production in EU. 22th. Worlds Poultry Congress; 2004 Jun 30-Jul 4; Istanbul. p. 928-9.

Ministry of Agriculture and Rural Affairs.. Statistics of organic agriculture; 2010. Available from: http://www.tarim.gov.tr/Sayfalar///lceriklerDetay. aspx? rid $=1085 \&$ NodeValue $=458 \&$ Konuld $=133 \&$ ListName= $=$ cerikler

Martino G, Ponzielli V, Grotta L. Healthier fat content through organic production. World Poultry 2008;24:33-34.

Thwaites L, Ferrier G, Sehnert J, Rea P, Killion M, Piotrowski J, Silverman S. NBJ's organic foods report 2004. Nutrition Business Journal 2004; $1: 1-424$.

NBJ. U.S. organic food sales (\$mil) 1997-2010e - chart 22. Penton Media: Nutrution Bussiness Journal; 2006.

Oberholtzer L, Greene C, Lopez E. Organic poultry and eggs capture high price premiums and growing share of specialty markets. United States Department of Agriculture, Outlook Report from the Economic Research Service; , 2006. 1-18

Owens C, Fanatico A, Pillai P, Meullenet J, Emmert J. Evaluation of alternative genotypes and production systems for natural and organic poultry markets in the U.S. 12th European Poultry Conferance; 2006 Sept 10-14; Verona. Italy. p. 62-3.

Padel S, Fowler S, Rajah K, McDougal I, Langstaff L, O'Regan T, Sharples T. Organic poultry production. In: Lampkin N, Wells R, editors. Final
Report to MAFF. Aberystwyth: Welsh Institute of Rural Studies, University of Wales; 1997

Ristic M. Meat quality of organically produced broilers. World Poultry 2004:20:30-31

Rodenburg TB, Van Harn J, Van Krimpen MM, Ruis MAW, Vermeij I, Spoolder HAM. Comparison of three different diets for organic broilers: effects on performance and body condition. British Poultry Science 2008:49(1):74-80

Rossiter L. Organic broiler chicken production trial Allee Farm. 2001 Available from: http://www.ag.iastate.edu/farms/2001 reports/nwallee/ OrganicBroilerReport. pdf

Seabrook M. Farm business survey 2005/06 poultry production in England. Reading: Department of Agricultural and Food Economics, School of Agriculture, Policy and Development, University of Reading; 2007.

Sheppard A. The structure and economics of broiler production in England [ Exeter: University of Exeter, Centre for Rural Research; 2004. Special Studies in Agricultural Economics, no. 59.

Sundrum A. Organic livestock farming. A critical review. Livestock Production Science 2001; 67:207-215.

Terin M, Yildirim I, Ciftci K. Chicken meat production and poultry meat consumption in Turkey and its progress. 2009. p.215-220. Available from: http://www.cabi.org/animalscience/Uploads/File/AnimalScience/ additionalFiles/WPSAAntalyaTurkey2009/11_terin_mps2009.pdf.

Tumer El. The effects of factors on death rate in the broiler farms. Journal of the Faculty of Veterinary Medicine, Kafkas University 2013;19(5):815820

USDA/AMS. Organic feed for poultry and livestock: availability and prices. 2003. Available from: http://www.ams.usda.gov/AMSV1.0/ getfile?dDocname $=$ STELDEV3013548

Van Calker KJ, Berentsen PBM, Giesen GWJ, Huirne RBM. Identifying and ranking attributes that determine sustainability in Dutch dairy farming. Agriculture and Human Values 2005; 22:53-63.

Van Den Tempel FCA, Giesen GWJ. Agrarische bedriifseconomie inleiding. Netherlands: Educaboek; 1992.

Vermeij I. Primaire productiekosten biologische kuikenvlees. Wageningen: Animal Sciences Group; 2004. p. 19. Intern rapport, 505. 